で, Sylvinite 鉱浮選の端緒となった Avirol 80 と同系統のモノ ゲンを主として使用し，浮選研究を行うととるに，水溶性塩類の 㻋水化機構についてる研究した。ぬれの䚀察法と浮選実験とを関 連させたのは，モビル油に気泡の役目を持たせたのであって，塩 類表面が界面活性剤の作用により瑓水化されれば, 前者の場合は 塩類は油を接着して沈降し, 後者の場合は気泡に接着して浮上す る。 $\mathrm{AgNO}_{3}, \mathrm{HgCl}_{2}, \mathrm{PbO}$ 等はこれに相当するが, $\mathrm{KCl}$ の場合 はよく観察すると，界面活性剤の作用によりモビル油と凝集状態 となったすのには気泡が相当に含まれ，この気泡に $\mathrm{KCl}$ の粉末 が接着して鉱化気泡になっている。前者の場合には試験管の内壁

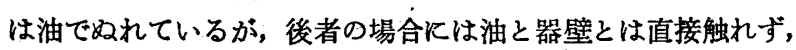
試験管を動かすと碗集状態になった内容物は容易に移動する。次 に NaCl が油にぬれるようになった場合は前 2 者と状態が異なり， 油被された粉末の集合が粗大で，沈降体積は大きい。 $\mathrm{AgNO}_{3}$ 等 の場合は気泡の含まれること少なく，沈降体積す小さい。沈降体 積の変化より浮選に関連して硫化鉱の表面酸化状態を調べ，また 沈降体積より吸着量が計算されているが10), 沈降体積, 凝集状態 の相違は，これら液底体表面に扣ける界面活性剤の状熊に差異の あることを示している。

一方, 強電解質の飽和溶液中にセッヶンを添加するのであるか ら,この系は塩析過程にある。したがって塩の飽和水溶液の塩析 力が界面活性阂隹，また液底体表面のぬれに影響を及ぽすのは当 然である。各種塩類飽和水溶液中に添加したセッヶンの安定性に ついて第 8 表の結果が得られた。

第 8 表 塩類飽和水溶液中に打ける界面活性剤の安定性

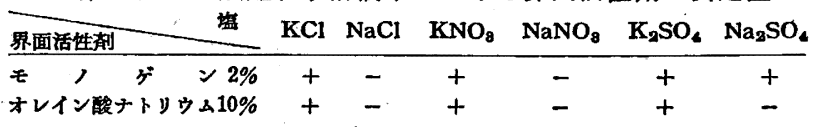

10）鐸木, 日化 62, 888 (1941).
実験法は試験管に $15 \mathrm{cc}$ の飽和水溶液をとり, 界面活性剤水溶 液 $0.5 \mathrm{cc}$ を加え, 10 秒間ふりまぜ, 1 昼夜放置後の状態を肉眼 で観察する。十は安定,一は塩析された場合である。実験温度 15 $\sim 20^{\circ} \mathrm{C}$ 。表中の塩類飽和水溶液では食塩が塩析速度最すはやい。 硫酸ナトリウム飽和水溶液中でモノゲンが安定状態を示すのに第 1 表深いてぬれの変化を示さないのは, これが多量の結晶水を 有するからで, 結晶水を有するるのは一般に眯水化され難い。

しかし塩類飽和溶液の塩析効果のみがぬれの变化を支配するな らば, 混合飽和溶液中では両液底体の最低消費量が一致しなけれ ばならないし，浮選法を行うことるできなくなるであろう。混合 飽和溶液中です最低消費量に差異の見られることは, 液底体の種 類によりその表面における界面活性剤の状態に相違のあることを 示している。ただ塩類溶液の塩析効果がぬれに影響を及ぼすこ とは，第 2 表 $\mathrm{NaCl}-\mathrm{KCl}$ 系に拈いて単独飽和溶液の場合のそれ ぞれの最低消費量は $\mathrm{NaCl} 0.90, \mathrm{KCl} 0.04$ で混合飽和溶液の場 合と著しく異なることによってもしれる。塩類表面に拈ける界面 活性剤の挙動については吸着実験等も行ってみたが，塩析過程に あるため考察が困難で決定的なことはいえない。

なお難溶性カリ塩としてメタリン酸カリを調製しモノゲン，オ レイン酸ナトリウムにより観察したが，ぬれの変化を示さなかっ た。したがって, 難溶性カリ鉱はこれらを捕集剤として浮選はで きないと考えている。Kuzin, Bureau of Mines の Sylvinite 鉱 浮選の報告では高品位, 高収率で $\mathrm{KCl}$ を得ているが, 第 3 表の 浮選結果は分離十分でない。しかし，モノダン濃度を低い状態に 保って浮選時間を長くすれば, 品位, 収率を向上することができ るであろ $5 。$

本研究を行 5 に当って中曾根荘三, 池田順二, 藤田秀雄, 椙田 衿の諸氏の援助を受けた。付記して謝意を表する。

\title{
（276） セッケン逆浮選による泉山陶石の脱鉄精製
}

(昭和 30 年 7 月 25 日受理)

\author{
川崎晴通・山本 妥三*
}

\section{1. 緒㝘}

案業原料の脱鉄精彆に関しては, 古くより水籍法が使用され, 磁気による分離も一部には採用されている。また塩素処理 法1), 加圧水熱法2), 浮遊選釷法3,4)等が報告されているが, いずれると れぞれ特長と欠点をもち，ことに浮選法による場合，可塑性の低 下3), 収率の不良 ${ }^{4)}$, 等の欠点がある。著者らは浮選法による場 合, 可塑性を低下することなしに, 高収量で鉄分を除去すること の可能性につき, 実験的に検討した結果, ある程度の結論を得た ので報告する。

* 長崎大学学芸学部：長崎市大橋町.

1). 鉿木, 工化 54,443 (1951).

2) 檜山, 名工大 3,263 (1951).

3) 久原, 佐賀等試 4, 1 (1951).

4) 川䗁, 長大学芸 4, 33 (1955).
1）試料 実験に供した試料は，佐賀県有田町泉山産の三等石 を,フレットミルで粉砕したすのから 120 メッシュの節下をとり 使用した。化学成分および耐火度は次のと扣りである゙。

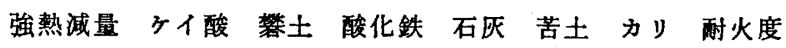
$\begin{array}{llllllll}3.74 & 78.20 & 14.06 & 1.19 & 0.56 & 0.43 & 2.50 & \text { SK } 72\end{array}$

この粉末試料をカキマゼ槽に入れ，水をみたし，20 分間はげし くかきまぜ大型試験管内で溉降させると，硫化鉄と思われる黄金 色粒子と酸化鉄拈よび磁硫鉄と思われる告色粒子が底部に堆積す る。また原試料を $(1: 1)$ 王水に一夜溶解し，鉄分を定量した結 果は䄪 $0.9 \%$ でありこれらのことは顕微鏡観察の結果と相ま口 て，鉄分の大部分は遊離の状態にあり，浮選および水籍には比較 的よく適した試料といえる。比較のために天草三等石について同 様に試みたが，同様な効果は期待できなかった。

5）草場, 佐賀窯試 4, 32 (1951). 
2）浮選方法 一般に陶石中の可塑性物質である綃雲母は浮揚 し易く，正浮選による場合鉄分とともに大部分澄流する。したが って適当な鉄分の抑制剤を使用すれば，絹雲母質のみを集めるこ とができる。しかしながら，泉山陶石は一般に可塑性弱く，これ より絹雲母質のみを集めることは採算上有利でなく，むしろ長石 質その他のヶイ酸程も集め収率を高くした方が有利である。硫化 鉄の抑制剤兼ケイ酸塩の活剤としては $\mathrm{Ca}(\mathrm{OH})_{2}$ および $\mathrm{Al}(\mathrm{OH})_{3}$ が知られているが, $\mathrm{Ca}(\mathrm{OH})_{2}$ は可塑性低下の括それがあるので 使用できない。本実験においては $\mathrm{Al}(\mathrm{OH})_{3}$ を活凪兼抑制風とし， オレイン酸ソーダを捕集剤とする逆浮選法を採用した。

\section{2. 実験経過および結果}

1）予借かきまぜ 粒子の表面が水溶液中で, 吸着, 化学反応 等のいわゆる浮選現象を起すためには，粒子の表面が十分に需れ ることが必要であり，予備かきまぜの影喰は無視できない。予備 かきまぜにより粒子表面近くの可溶性成分溶出し，また粒子表 面は水溶液中のイオンと交換して安定化する。乾燥試料 $10 \mathrm{~g}$ お よび酢酸アルミニウム $0.2 \mathrm{~g}$ を水道水中でかきまぜ, 経過時間と 水溶液の $\mathrm{pH}$ との関係を求めた結果を第 1 図に示す。この結果よ り予備かきまぜ時間を 20 分間と決定した。
第 1 因

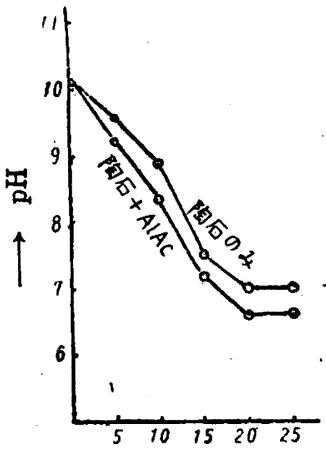

$\longrightarrow$ —きまぜ時間 ( $\mathrm{min})$
第 2 因

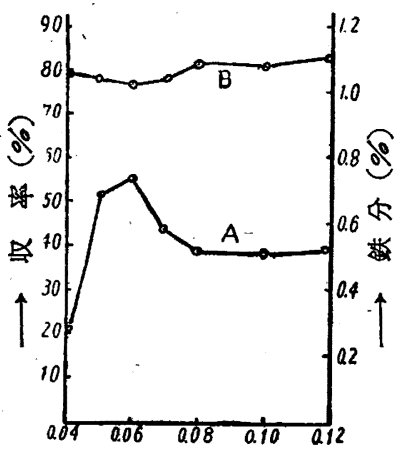

一オレイン酸ソーダ(g)
2）浮遊選鉱試䀦機 試験機としては MS 型 $50 \mathrm{~g}$ 浮選機を使 用した。まず試料 $10 \mathrm{~g}$ および醮酸アルミニウム $0.2 \mathrm{~g}$ を入れ水 をみたし，20 分間かきまぜたのちオレイン酸ソーダ水溶液を加 え，10 分間浮選を行った。第 2 図AK示したよろにセッケン使用 量の增加ととすに収率は增加するが，十分でなく，かつ第 2 図B に示したように鉄分の除去はほとんど行われない。

機械的条件をいろいる变えて浮選を行った結果は, 次の方法が 最す良好であうた。すなわち，予備かきまぜは，下部インペラー のみで行い，浮選は上部インペラーのみで行うのである。かくす るときは，気泡発生の増加ととすに陶石と鉄分との比重差が併用 されて，第 3 図Cに示すよ弓K収率る堌加し，鉄分すDK示すよ 5に娍少し，かつ収率の增加にとるなう鉄分の增加がほとんどな い。したがって，以後の実験においては，鉄分の除去は機械的条 件に任せ，収率の增加をおるに考えることとした。

3）陶石のみの浮選一般に陶石はその鉣物組成であるケイ酸 塩の種類より考えて，それ自体相当の浮遊度が期待される6)。した がって，陶石のみをオレイン酸ソーダにより浮選を行ったところ 第 4 四の収率曲線を得た。水道水による浮選の収率が高いのは, 含有多価イオンの影㖓と考えられる。

6) 林, 浮選 p. 378 383 (工元社).
第 3 図

第 4 因

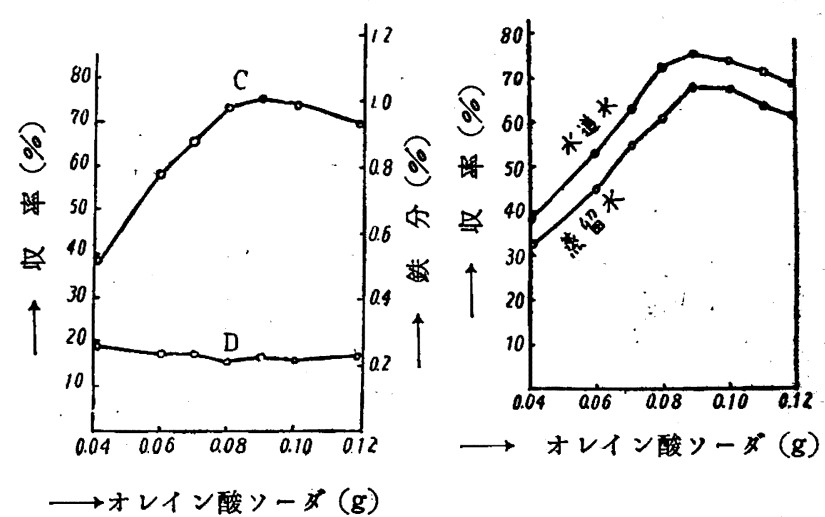

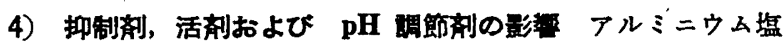
類を活剤として使用する場合，長石打よび絹雲母に対しては $\mathrm{pH}$ =6.5 8.0 内に最適条件が考えられるが6)，硫化鉄の揤制剂とし ては水酸化アルミニウムであるから， $\mathrm{pH}=7.0$ ～8.0くらいが適 当と考えられる。実際には $\mathrm{AlCl}_{3}$ および $\mathrm{NaOH}$ を使用すべきて あるが，本実験に使用した試験機は小型のため $\mathrm{pH}$ の変動はなは だしく，やむをえず酢酸アルミニウムを使用した。酢酸アルミニ ウムは水に溶けにくく，粉末結晶をそのまま投入したため多量を 必要としたが，オレイン酸ソーダを加えることにより，パルプの $\mathrm{pH}$ は大体予定の範围内に括さめることができた。第 5 図は陶石 $10 \mathrm{~g}$ ，オレイン酸ソーダ $0.04 \mathrm{~g}$ を使用した場合，醀酸アルミニ ウムの添加量に対する収率の変化を示す。これにより酢酸アルミ ニウムの場合は, $0.2 \mathrm{~g}$ 程度が適当と考えられ, 醀酸アルミニウ ム $0.2 \mathrm{~g}$ を添加した場合, セッケン量の変化に対する収率の変化 を第 6 図に示寸。水道水による収率の低下はなんらかの妨害イオ ンによるるのと思われる。
第 5 図

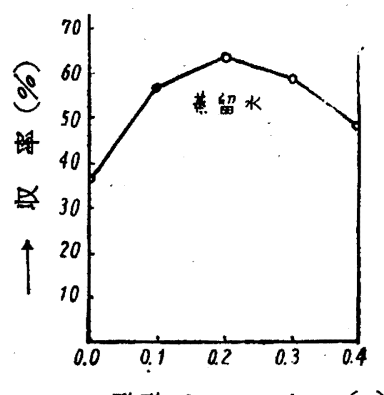

$\longrightarrow$ 酢酸アルミニウム $(\mathrm{g})$
第 6 図

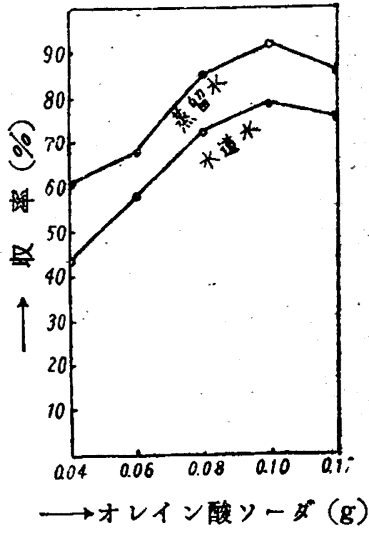

5）条件付与による水筑との比交 従来陶磁器工場において は，整粒扣よび鉄分除去のために水籍法が採用されているが， ト ロンメル内で粉砕したるのを，そのまま水期タンクに導き，水籍 しているため，泉山三等石の上5なるのは鉄分は $0.7 \%$ 程度にし か低下しない。しかし粉砕試料を水中で強くかきまぜれば解囯さ れ，比重差による分離がよくなる。付表Aは試料 $30 \mathrm{~g}$ を浮選機 のカキマゼ槽に入れ，水をみたし，下部インペラーのみを使用 し，3,000 rev/min て 20 分間かきまぜたのち，カキマぜ槽の底 部より水を $100 \mathrm{cc} / \mathrm{min}$ の割合で注入し，かつインペラーの高さ をカキマゼ槽の中ほどに位置せしめ, $750 \mathrm{rev} / \mathrm{min} て ゙$ 回転しつ ・つ, 10 分間澄流させた結果を示す。すなわち，解膠はされてす 
分離は十分でない。

オレイン酸ソーダは解膠凧であるから, 試料にオンイン酸ソー ダを加えて水中でかきまぜれば，解曑されて分離がよくなるはず であるが, オンイン酸ソーダは捕集剤, 起泡剤としてる㗢き, 鉄分 を浮揚せしめ分離が覀くなる。しかしながら，上記と同様の浮選 条件を与え，水䇦を行えば浮選と同様の結果が得られることる考 えられるので, 次の実験を行った。すなわち試料 $30 \mathrm{~g}$ と酢酸ア ルミニウム $0.4 \mathrm{~g}$ を浮選機のカキマゼ槽に入れ水をみたし，10 分間下部インペラーのみでかきまぜ,オンイン酸ソーダ水溶液を 加え,さらに 10 分間かきまぜ $\mathrm{A}$ と同様の方法で水䇦した結果も B に示す。付表Cは類似条件による浮選の結果である。

\begin{tabular}{|c|c|c|c|c|}
\hline & 附 & $\begin{array}{c}\text { 表 } \\
\mathrm{A}\end{array}$ & B & C \\
\hline 試 & (g) & 30 & 30 & 30 \\
\hline 酢酸アルミニウム & $(g)$ & 0 & 0.4 & 0.4 \\
\hline オンイン酸ソーダ & $(\mathrm{g})$ & 0 & 0.18 & 0.18 \\
\hline 予備かきまぜ時間 & $(\mathrm{min})$ & 20 & $10+10$ & 20 \\
\hline 同上終点 $\mathrm{pH}$ & & 7.0 & 7.4 & 6.8 \\
\hline 浮選時間 & $(\min )$ & - & - & 10 \\
\hline 同上終点 $\mathrm{pH}$ & & - & $=$ & 7.2 \\
\hline 収率 & $(\%)$ & 82 & 84 & 78 \\
\hline 精撆物鉄分 & $(\%)$ & 0.74 & 0.71 & 0.22 \\
\hline
\end{tabular}

すなわち, 水籍による場合, 脱鉄は十分でなく, 逆浮選によって はじめて高収率で鉄分の除去率を高めることができる。表から見 るように, アルミニウム塩類扣よびオンイン酸ソーダの使用量多 く経済的には不利のよ5にみえるが，大型の浮選機を使用し，ア ルミニウム塩として塩化アルミニウム水溶液を用いれば，使用量 をかなり下げることができる。

逆浮選法により得た精製物は，セッケンによりコロイド質が凝 析している結果, 沈降速度が大きくかつロ過速度も大である。精 製物をNo. 2 定性口紙にて口過した結果は大体 15 分以内に口過 が可能であるが，水籍物では 40 分以上を必要とした。すなわち, このことより工業的にはフィルタープレスによるロ過脱水の場合 動力費の節減に役立つるのと考えられる。

\section{3. 哧語}

アルミニウム塩を活剤兼抑制剤としてオンイン酸ソーダを捕集 剤とする逆浮選法により, 泉山陶石の脱鉄精製を試みた結果, 浮 選機のインペラーの位置の変化により，収率 75〜80\%にて鉄 分 $0.20 \sim 0.25 \%$ の精製物をらることができた。な敃在起泡剤 のみによる浮選につき検討中である。 